\title{
Neotropical coastal lagoons: An appraisal of their biodiversity, functioning, threats and conservation management
}

\author{
Esteves, FA. *, Caliman, A., Santangelo, JM., \\ Guariento, RD., Farjalla, VF. and Bozelli, RL. \\ Laboratório de Limnologia, Departamento de Ecologia, \\ Universidade Federal do Rio de Janeiro - UFRJ, \\ CP 68020, CEP 21940-540, Rio de Janeiro, RJ, Brazil \\ *e-mail: festeves@biologia.ufrj.br
}

Received October 8, 2007 - Accepted October 8, 2007 - Distributed November 30, 2008

\begin{abstract}
Neotropical coastal lagoons (NCL) are human-dominated ecosystems. Their distribution along densely populated coastal areas of developing countries makes these systems among the most threatened in the world. Here, we summarize some aspects of the causes and consequences of NCL biodiversity, their functioning, their importance to the surrounding populations, their fragility, and their responses to local and global anthropogenic impacts and the challenges that Neotropical countries face in conserving these systems. Although still scarce and geographically concentrated, a growing body of studies has shown that NCLs are physiographically diversified systems, which harbor a considerable and particular proportion of the Neotropical inland aquatic biodiversity. Despite the fact that coastal lagoons are ecotones that are intricately connected to surrounding environments, they develop mechanisms for structural and functional regulation, which confer to these systems higher productivity and carrying capacities than surrounding ecosystems. Such traits attract residential developments and subsidize local traditional populations with important economic and aesthetic ecosystem revenues such as fisheries and scenic beauty. However, the disorganized human occupation around NCLs are causing profound impacts such as eutrophication, salinization, exotic species introduction, as well as other effects, which are ultimately imposing major habitat degradations and biodiversity extirpations in NCLs. We argue that interdisciplinary conservation strategies, which integrate scientific expertise, government officials, private companies and the general public, are the most likely to overcome the geographic and economic obstacles to NCL conservation.
\end{abstract}

Keywords: coastal ecosystems, ecosystem management, shallow lakes, human impacts, tropical limnology.

\section{Lagoas costeiras neotropicais: Uma apreciação sobre sua biodiversidade, funcionamento, principais ameaças e estratégias de conservação}

\begin{abstract}
Resumo
As lagoas costeiras neotropicais (LCN) estão inseridas em um ambiente antropogênico. Sua localização em regiões costeiras densamente povoadas de países em desenvolvimento coloca estes ecossistemas entre os mais impactados do mundo. Neste trabalho, resumimos vários aspectos relacionados às causas e conseqüências da sua biodiversidade, seu funcionamento e os bens proporcionados à população do seu entorno. Sua fragilidade e as respostas a impactos humanos locais e globais, assim como os desafios para a sua conservação por países neotropicais, também são abordados. Apesar de escassos e geograficamente concentrados, um número crescente de estudos tem mostrado que as LCN são sistemas fisiograficamente diversificados, abrigando uma proporção considerável da biodiversidade dos ambientes aquáticos continentais neotropicais. Apesar de as lagoas costeiras representarem ecótonos bastante conectados ao ambiente adjacente, elas desenvolveram mecanismos próprios de regulação funcional e estrutural, conferindo uma maior produtividade e capacidade de suporte em relação aos ambientes circundantes. Tais características estimulam o desenvolvimento humano ao seu redor e subsidiam populações tradicionais locais com benefícios econômicos e estéticos como pesca e beleza cênica. No entanto, a ocupação desordenada de regiões próximas às $L C N$ vem causando profundos distúrbios como eutrofização, salinização, introdução de espécies exóticas e outros, os quais acarretam a degradação do hábitat e a perda de biodiversidade. Acreditamos que estratégias de conservação multidisciplinares, que integrem conhecimento científico, órgãos governamentais, companhias privadas e opinião pública, são as mais indicadas para sobrepor os obstáculos geográficos e econômicos impostos à conservação das LCN.
\end{abstract}

Palavras-chave: ecossistemas costeiros, manejo de ecossistemas, lagos rasos, impactos antrópicos, limnologia tropical. 


\section{Introduction}

The activities of modern human society have driven the most dramatic and unprecedented mass extinction event on earth, with the current rates of global species loss exceeding 1,000 times those observed from fossil records (Millennium Ecosystem Assessment, 2005). Among regions, the majority of extinctions are occurring in the tropics, the regions of the highest biodiversity. Among ecosystem types, inland aquatic systems are arguably the most impacted because human reliance on freshwater leads to a concentration of human activities on these systems (Ricciardi and Rasmussen, 1999; Sala et al., 2000). This scenario suggests that Neotropical coastal lagoons (hereafter called NCLs for brevity), whose continental coastline distributions coincide with densely-populated areas in the Neotropics, are probably among the most human-dominated and threatened ecosystems on earth (Berkes and Seixas, 2005). This fact, along with the concern that coastal lagoons are valuable and representative components $(\approx 12.2 \%$ South America coastline) of coastal areas in terms of both ecosystem and natural capital (Gönenç and Wolflin, 2004), indicates that NCLs should be a priority among the conservation planning of natural ecosystems in Neotropical countries (Esteves et al., 2002; Barbosa et al., 2004).

Although there is considerable knowledge about the consequences of anthropogenic impacts on the structure and function of coastal lagoons worldwide, the documented cases of successful initiatives directed toward the protection and restoration of these systems are almost exclusive to the Mediterranean coast (Lardicci et al., 2001; Gikas et al., 2006; Tsihrintzis et al., 2007), with a few exceptions regarded to NCLs (Botero and Salzwedel, 1999; Esteves et al., 2002; Barbosa et al., 2004). The paucity of conservation efforts is not only prejudicial to NCL biodiversity in its own right but has already been shown to constrain the capacity of these systems in providing important ecosystem revenues, such as fisheries, recreation and clean water, to local societies (Macintosh, 1994; Esteves, 1998; Gönenç and Wolflin, 2004).

In this work, we present a synthetic review of some aspects such as the origin (e. g. geomorphology), structure (e. g. biodiversity and physical environment), functioning (e. g. main ecosystem processes and services), impacts, and conservation possibilities for NCLs. Our main objectives are: 1) to ask whether NCLs have more species than their temperate counterparts; 2) to show that NCLs sustain similar biological diversity comparable to other continental aquatic ecosystems in the neotropics; 3 ) to show that NCLs are important depositories of endemic species; 4) to identify physiographic traits which are responsible for singular aspects of NCL structure and functioning; 5) to evidence how local anthropogenic activities, as well as human-mediated global change, may severely impact the biodiversity and functioning of NCLs; and 6) to indicate why a multidisciplinary conservationbased strategy is the best choice for protecting NCLs.
Although we recognize that coastal lagoons worldwide share many traits related to their origin, structure, functioning and threats, they also show a particular distinction with respect to both ecological and socio-economic characteristics of their surrounding environments and local human populations. Thus, we focused our approach on examples derived from the Neotropical region, more specifically from South America coastal lagoons, where the number of published studies is higher (Kjerfve, 1994; Agostinho et al., 2005).

\section{Definition and Geomorphology of Coastal Lagoons}

Coastal lagoons can be broadly defined as natural lentic water bodies distributed along the continental shoreline. However, sometimes coastal lagoons are confused with other coastal inland aquatic ecosystems, such as salt marshes and estuaries. Thus, coastal lagoons can be precisely defined as shallow aquatic ecosystems that develop at the interface between coastal terrestrial and marine ecosystems and can be permanently open or intermittently closed off from the adjacent sea by depositional barriers (Kjerfve, 1994; Gönenç and Wolflin, 2004). Water can span the range of salinities from hypersaline to completely fresh depending on the relative strength of the particular drivers of their hydrological balance, such as local precipitation, watershed inflow, evaporation and sea-water intrusion by percolation through, or overtopping of, the sand barrier (Bird, 1994; Smith, 1994).

The geophysical characteristics that contribute to the coastal lagoons' hydrological balance are so important and so strongly affected by the physical processes that govern lagoon genesis and their geomorphological evolution, that they are used as criteria for identifying different types of coastal lagoons. The first criterion considers the current state of the system with regard to its connectivity with the sea. Lagoons can be lentic non-tidal (without a permanent connection with the sea) or lentic microtidal (permanently connected with the sea) (McLusky and Elliott, 2007). The second criterion considers a lagoon's origin. In general, NCLs mostly originated from the flooding of lowland coastal areas due to the rise in sea-level during the worldwide Late Quaternary marine transgression (Caldas et al., 2006). The lagoons originating by these processes generally have large surface areas (e. g., Lagoa dos Patos, $10.200 \mathrm{~km}^{2}$ located in the extreme south of Brazil) and are positioned parallel to the coastline, which increases the marine influence on lagoon water due to the higher probability of waveoccasioned marine intrusions. Other common types of NCLs are those formed by the action of marine tides and waves, which build up a depositional barrier across a river mouth (Esteves, 1998). These coastal lagoons are, in general, perpendicular to the coast with a branched configuration and a high perimeter to area ratio, and are formed from the flooding of river valleys. High amounts of both dissolved and particulate terrestrial material en- 
ter into these systems as a corollary of such morphometric patterns (Panosso et al., 1998). Although in most of the cases these lentic non-tidal branched coastal lagoons are completely freshwater systems, some rare marine storms can increase salt concentration in regions closer to the sea, which may confer a polarized salinity condition to these lagoons (Attayde and Bozelli, 1998). The heterogeneity of morphometric and geomorphological dynamics observed among NCLs is an important aspect, creating a vast array of ecological gradients and microhabitats, which are crucial in supporting both local and landscape biodiversity (see discussion below). There are other less representative kinds of coastal lagoons, such as temporary systems formed during the rainy seasons, as ponded waters in depressions on soft sedimentary shores. A complete appreciation about the coastal lagoon geomorphology can be accessed in Bird (1994).

\section{Patterns in NCL Biodiversity}

One of the most pervasive and long-standing patterns in Ecology is the astonishingly high number of species observed in the tropics in comparison to that of temperate regions (Gaston, 2000). Although the relatively small number of studies does not allow complete confidence in this latitudinal trend in coastal lagoons worldwide, some isolated assessments shed light on this possibility to at least some groups of organisms. We ran a bibliographic survey in the website of Institute for Scientific Information (Thomson corporation, 2007), searching for the terms "coastal lagoon", "biodiversity" and "diversity". We found 87 published studies, from which only $27(31 \%)$ referred to NCLs. The existing studies suggest that for a variety of communities such as benthic invertebrates, fish and waterfowl (Veiga et al., 1995; Esteves, 1998; Garcia et al., 2006) the number of species registered in NCLs is on average higher than those observed in temperate ones. We believe that the NCL biodiversity is underestimated since most of the works performed in the Neotropical region were not specifically designed as lagoon biodiversity inventories, and because the information is so diffuse and fragmentary (i.e., published in nonindexed journals) that it is difficult to generate a comprehensive assessment about NCL biodiversity (Lewis, 1987). For example, Van Sluys et al. (2004) carried out a unique study on amphibian (most specifically anurans) biodiversity in NCLs, but this study was published as a book chapter, diminishing the dissemination of that information. The inclusion of such information in NCL biodiversity assessments would certainly exacerbate biodiversity differences between Neotropical and temperate coastal lagoons, since the number of anuran species in the temperate region is recognizably low. Another important observation that needs to be accounted for is the relatively short spatial scale at which studies in NCLs are carried out. For example, most of the published studies on Brazilian coastal lagoons were developed only in the southeast and southern region of the country
(Esteves, 1998; Esteves and Lacerda, 2000). Since there are compelling topographic and climatic discontinuities along the Brazilian coastline, such a geographical bias in sampling effort may greatly underestimate the regional biodiversity of NCLs. We stress the need for implementing broader spatial (also within the environment) and temporal biodiversity inventories in NCLs to expand the boundaries of our information about the patterns of occurrence, distribution and threats of NCL biodiversity.

Most of the first studies carried out in NCLs were focused on large, sea permanent-connected coastal lagoons, at which salt concentrations are similar to the sea. These systems are generally species poor since salinity represents a severe biological filter against the establishment of a set of organisms such as aquatic macrophytes (Esteves, 1989), zooplankton (Schallenberg et al., 2003), fish (Sosa-López et al., 2007) and others. On the other hand, a proportionately low number of studies was developed in small lagoons that were either permanently or intermittently closed, and at which freshwater conditions predominate most of the time or may alternate in space or time between brackish or freshwater states. We argue that such a bias towards these study systems contributed to a generalized impression that coastal lagoons are species poor aquatic systems with a low occurrence of endemism compared to other inland aquatic systems (Margalef, 1983). However, recent studies carried out on small, intermittently closed-off NCLs have indicated an opposing pattern. For example, Lopes (2005) and Santangelo (2005) registered almost 180 zooplanktonic species in Cabiúnas lagoon (southeast Brazil). Other studies developed in other permanently or intermittently closed off coastal lagoons of the same region also registered a high number of zooplankton species (Reid and Esteves, 1984; Branco et al., 2000). Such values observed for crustacean zooplankton species richness are equivalent to those registered in some Amazonian floodplain lakes (Carneiro et al., 2003) and higher than some values registered in Amazonian altitudinal lakes (Bozelli, RL. unpublished data).

Another important question that needs to be considered regarding NCL biodiversity is their importance as a cradle of species endemism. The relatively short evolutionary time of coastal lagoons (most originated within the last 7,000 years) suggests that such systems have small potential as cradles of biological speciation. This fact, taken together with the knowledge that coastal lagoons are separated from surrounding ecosystems by weak geographical barriers, lead evolutionary ecologists to argue that such systems have a low potential to harbor endemic species (Margalef, 1983). However, an increasing number of studies are discovering the occurrence of new endemic species belonging to a vast group of aquatic communities such as zooplankton (Reid, 1985; de Paggi et al., 2000), phytoplankton (Melo et al., 2003) and protozoa ciliates (Paiva and Silva-Neto, 2005). Therefore, the idea that coastal lagoons do not harbor endemic spe- 
cies has been refuted, at least for small short-lived organisms.

\section{Causes of NCL Biodiversity}

Some hypothesis may be directed toward the elucidation of the patterns of NCL biodiversity identified above, although we recognized that specific studies need to be conducted for further validation of this hypothesis. However, our purpose in this review was not to show any conclusive facts, but instead, to summarize patterns and identify research needs regarding the ecological knowledge about NCLs. Thus, we believe that the proposition of a hypothesis about the causes of biodiversity in NCLs may be a provocative step to encourage neotropical limnologists, taxonomists and evolutionary ecologists to start to pursue such answers.

A growing body of evidence has demonstrated a negative correlation between salinity and species richness in coastal lagoon biodiversity, either when the salinity effects are demonstrated across lagoons (Schallenberg et al., 2003; Sosa-López et al., 2007) or when it is demonstrated spatially and temporally in a same lagoon (Attayde and Bozelli, 1998; Santangelo et al., 2007). However, other studies have shown some positive effects of salinity on NCL biodiversity (Koslowsky-Suzuki and Bozelli, 2004), indicating that effects of salinity can be context dependent. Considering that salinity disturbance is almost a pervasive phenomenon in coastal lagoons and that salinity can affect species directly (first order effects) and indirectly (higher order effects) (Santangelo, 2005), we credit salinity fluctuations as one of the most important ecological drivers in structuring NCL biodiversity at both local and regional scales. We propose that the strength and direction of salinity effects on both local and regional NCL biodiversity will depend on whether the intensity of its spatial and temporal effect will be weak enough to avoid species extinction and strong enough to promote species coexistence. Locally, salinity increases may reduce coastal lagoon biodiversity if its effect is strong enough to directly extinguish physiological-sensitive species (Santangelo et al., 2007) or indirectly extinguish species that are important in stabilizing species interactions. (e.g. aquatic macrophytes; Esteves, 1989). On the other hand, mild local spatio-temporal variations in salinity may promote biodiversity if it diminishes species dominance or creates new microhabitats or ecological gradients (e.g. salinity stratification) that permit relict biotic elements from either fresh or marine origin to coexist (Attayde and Bozelli, 1998; Koslowsky-Suzuki and Bozelli, 2004). Regionally, salinity will reduce coastal lagoon biodiversity if its spatio-temporal effects are pervasive and strong enough to homogenize species composition across ecosystems (Schallenberg et al., 2003; Sosa-López et al., 2007). However, if the spatial and temporal effects of salinity are discontinuously distributed among coastal lagoons, salinity can promote regional biodiversity by diversifying species composition across ecosystems. Such patterns have been observed for a variety of communities from bacteria (Laque, 2006) to fish (Caramaschi et al., 2004). Since most of the NCL are shallow and relatively small water bodies, their biodiversity is also supposed to be dependent on characteristics such as size, depth and shape, which are important to aquatic ecosystem diversity since they mediate the rates of species colonization, food chain length and aquatic vegetation cover (Scheffer, 1998).

The unexpected occurrences of endemic species in coastal lagoons are of conservational, ecological and evolutionary interest. Although coastal lagoons have a relatively short evolutionary age and loose geographical barriers, which are basic aspects in promoting speciation, they show temporal and spatial discontinuities in ecological characteristics (see discussion above) that may be important to promoting character displacement and isolate phenotypes in populations of short-lived organisms such as small crustaceans, micro algae and ciliate protozoa. Such compact ecological gradients can be sufficiently stable over time to induce behavioral changes and expose individuals to new selective pressures by altering the way that organisms interact with the environment, thus driving evolutionary divergence of small organisms. For example, it has been suggested that mutational rates in small organisms such as nematodes are accelerated in the presence of humic substances (Steinberg, 2003), which show very high and variable concentrations in many NCLs (Farjalla et al., 2002; Suhett et al., 2007). Another possibility to produce fast evolutionary diversification might also be mediated by trophic interactions in planktonic food webs, when prey species with fast generation times are more susceptible to rapid evolution by predator selection (Yoshida et al., 2003). We propose that future work should ask if endemism in NCLs can be promoted by local discontinuities in geophysical conditions and/or specific predator-prey interactions that promote fast speciation in small organisms.

\section{Consequences of NCL Biodiversity}

As we have discussed so far, and as will be presented in the following sections of this paper, NCLs are regionally species-rich aquatic systems that supply important ecosystem services such as fishing, recreation and clean water, to human societies, but are increasingly threatened by anthropogenic impacts (Esteves, 1998). The increasing rates of biodiversity loss in such aquatic systems can drastically impair the capacity of NCLs to provide important ecosystems services that local societies rely on. The ecological fundamental of this scientific inquiry is that species are divergent in the way they capture available resources. Therefore, the more species an ecosystem has, the greater the proportion of the total available resources that are captured (Hooper et al., 2005) and can be converted, for example, into animal biomass. Although there is a hot debate around this theme in the international ecological literature, it has been surpris- 
ingly neglected among Neotropical aquatic ecologists (Caliman, 2005a). However, notably, the few studies carried out in Neotropical aquatic systems have been conducted in coastal lagoons.

Caliman (2005b) explicitly demonstrated that the biodiversity of benthic invertebrate bioturbators from the Imboassica coastal lagoon (Southeast Brazil) altered the rates and ratios of nutrient flux across benthic-pelagic habitats to an extent that could not be predicted by the sum of individual species' effects. The increase in bioturbator biodiversity lead to a monotonic increase in the production of the pelagic bacterial community, because higher benthic biodiversity improved the quantity (i.e. increased flux) and quality (i.e. decreased ratios) of dissolved organic carbon, nitrogen and phosphorus released from sediment to the water (Caliman, 2005b). In another study carried out in the same coastal lagoon, Caliman et al. (2007) showed that benthic biodiversity also had a positive effect on the stability of the phosphorus flux between the sediment and water. Suhett (2007), studying the effects of macrophyte litter biodiversity on their decomposition processes in a Brazilian coastal lagoon, also showed that as litter species richness increased, there was a significant reduction in microbial respiration, indicating that biodiversity of aquatic vegetation may, for example, reduce the risk of fish mortality by minimizing oxygen depletion in the water column. These results show that the biodiversity of different communities is important in driving the magnitude and stability of a variety of fundamental ecosystem-level processes, such as aquatic nutrient cycling and productivity. Since NCL communities are constantly affected by natural disturbances and anthropogenic impacts, such as eutrophication, species introductions and habitat destruction, future work should be devoted to determining how changes in NCL biodiversity will alter the capacity of these ecosystems to perform vital ecological processes and supply indispensable ecosystem goods and services to local societies.

\section{The Functioning, Process and Services of NCL}

NCLs experience forcing from river input, wind stress, tides, precipitation to evaporation balance, different salinity regimes and many man-induced changes (Kjerfve, 1984). All of these factors make these systems unique compared to other aquatic ecosystems and are also responsible, with different weights, for the overall functioning and services that these systems provide.

Acknowledgement of the dynamics of abiotic factors is central to the understanding of the biological, chemical and physical properties of coastal lagoons. For example, fluxes of water control the flushing of a lagoon, thereby maintaining water quality, and provide a mechanism for the import and export of nutrients and planktonic organisms. Salt fluxes determine the overall characteristics of the lagoon and heat fluxes control the warming and cooling (Smith 1994). Despite the considerable body of literature on these subjects, few were conducted in NCL coastal lagoons, and general remarks point out the relationship between water, salt and heat budgets with lake geomorphology. Geomorphologic factors include inlet and outlet configuration, lagoon size and orientation with respect to existing wind direction, bottom topography and depth. Inlet dimensions control the exchange of water, including dissolved and suspended material. Wind effects will be enhanced in larger lagoons, and will be determinant in gas exchange and water mixing. The bottom topography of the lagoon, including both natural and man made channels, plays an important role in guiding the tidal and non-tidal circulation and thus controlling advective transport. Finally, depth may be the most important of the factors listed above. The shallowness of coastal lagoons with a large surface area to mean depth ratio, determines several hydraulic, hydrographic and ecological features as a direct consequence. Shallow water is especially responsive to heating and cooling process. Esteves (1989) pointed out that depth is responsible for the different patterns of water stratification of tropical and temperate lakes. The range of temperatures in the tropical region can be greater during a day than that observed along seasons through the year. So the stratification and destratification processes in NCLs often occur during one day and not along climatic seasons.

In shallow waters, wind may promote significant wave action, and thus mixing can extend to the bottom, promoting, in many cases, the resuspension of the sediment by water movement. A review of field studies in a range of aquatic ecosystems showed that $85 \%$ of the resuspendend matter flux to the sediment may be due to resuspended material (Evans, 1994), and that such processes may be an especially dominant cause of turbidity in large shallow lakes (Sheffer, 1998). Although sediment resuspension may be most associated with wave action, bottom-feeding activity may also cause sediment resuspension (Caliman, 2005b). Scheffer et al. (2003) evaluated the interaction between wave and animal activity on sediment resuspension. Through field and laboratory experiments, they showed that fish holes on the sediment decreased sediment resistance to wave actions and thus enhanced sediment resuspension (Scheffer et al., 2003). These results imply that management activities to restore clear-water state in NCL that are turbid due to wind resuspension must take in account the fauna that inhabit the systems. Morphometric features such as the perimeter to volume ratio and shallowness also provide favorable conditions for the development of a large littoral region (Kjerfve, 1994), where many macrophyte species segregate along the littoral-zone slope, providing a substantial source of organic matter to the system and substrate for attached organisms. Once an NCL fits such a description it must follow the tendency on the global scale, where lake littoral zones exceed pelagic zones by both area and productivity (Wetzel, 1992).

Due to their geomorphologic origin and the proximity with the ocean, NCLs are strongly influenced by 
salinity. Despite their influence on the physiology and distribution of organisms within and between habitats, recent studies point to salinity as an important driver for regime shifts in shallow lakes (Jeppesen et al., 2007). Changes in salinity may have direct effects on the structure of the zooplankton community. At low salinities, large herbivores are favored (Jepessen et al., 1994), while at high levels of salinity phytoplankton control is exerted only by small and/or selective filter feeders (Jepessen et al., 1994). So, a potential increase in salinity induces a shift from the clear to the turbid state in a non-linear way, and the threshold for such a shift depends on both predation pressure and nutrient loading (Jeppesen et al., 2007). Therefore, salinity control has direct implications for NCL management at present and future (predicted) warmer climates. Better water quality can be obtained through improving freshwater inputs; fish manipulation is not useful in brackish lagoons, unless the salinity is below the threshold that enables large herbivores to dominate; and finally, more abrupt changes will be expected in low-salinity coastal lagoons during summer in a future warmer climate (Jepessen et al., 2007).

Coastal lagoons also present a high degree of connectivity to adjacent land and ocean ecosystems, exhibiting a significant exchange of water and particulate and dissolved materials (Smith and Atkinson, 1994). Materials that enter lagoons via watersheds, runoff from surrounding areas or ground flow react in the lagoons, accumulate in the sediments or are removed to the ocean without reaction. Studying four NCLs in the north of Rio de Janeiro state (Brazil), Farjalla et al. (2002) observed high concentrations of dissolved organic carbon (DOC), comparable to concentrations often found in swamps and ecosystems considered rich in dissolved organic matter (DOM). Due to C:N ratios and other specific characteristics of the DOC, the authors attributed the origin of that carbon to the partial decomposition of macrophytes and mostly to the decomposition of terrestrial plants in the surrounding area, once the watershed was dominated by coarse-sand soil, easily permeable to DOM. NCLs may also represent a source of energy and nutrients to adjacent areas; for example DOC derived from aquatic plants provides a major source of energy to coastal marine bacterioplankton (Moran et al. 1991). Stepenauskas (1999) showed that bioavailability of DOM is enhanced after mixing of lake and ocean water. However, studying Cabiúnas lagoon (Northeast Brazil) that author showed that DOM of the ocean were more bioavailable than lake DOM, a result that corroborates previous cross-system comparisons (Søndergaard and Middelboe, 1995).

Let us briefly consider the dynamics of main nutrient elements such as phosphorus, nitrogen and sulfur. First of all we must consider that if lagoons are net producers of organic matter, then these systems might be expected to take up dissolved inorganic nutrients from terrestrial delivery and/or oceanic exchange. If these systems are net consumers of organic matter, the net oxidation should release dissolved inorganic nutrients, which will then be transported to the ocean or adjacent areas. Smith et al. (1991) point out that the uptake or release of phosphorus can be interpreted to follow the general trend of nutrient uptake or release during oxidation of organic matter. However, the phosphorus transformation on aquatic ecosystems may suffer potential interference of abiotic reactions, such as adsorption-desorption or co-precipitation. Based on studies conducted in estuaries, Smith and Arkinson (1994) assume that most phosphorus fluxes in coastal lagoons may be attributed to biochemical reactions, since geochemical transformations may be very sensitive to salinity. Panosso and Esteves (2000), studying Cabiúnas and Imboassica coastal lagoons in Rio de Janeiro state (Northeast Brazil), observed that bacterial and algal phosphorus mineralization through extracellular hydrolysis could provide 48 times the minimum amount of inorganic phosphorus necessary to phytoplankton and bacterioplankton growth in the Imboassica lagoon. However, extracellular hydrolysis of phosphorus was of minor importance in the Cabiúnas lagoon. Cabiúnas is a DOC rich system with high concentrations of humic substances, which can inhibit the activity of extracellular enzymes (Wetzel, 1991). The authors suggest that in systems with high concentrations of humic substances, other mechanisms, such as photo-degradation, may have a larger influence on the phosphorus mineralization process. As mentioned in the sections above, many NCLs are rich in humic substances and show DOC derived from the partial decomposition of aquatic and terrestrial plants. Panosso and Esteves (2000) point out that the difference in the quality of the dissolved organic matter in coastal lagoons can have direct effects on the relative importance of different mechanisms responsible for the phosphorus mineralization in these systems, with potential implications for its overall functioning.

The nitrogen flux could be also interpreted to arise from simple production or consumption of organic matter. However, it is actually more complex because of $\mathrm{N}_{2}$ fixation and denitrification processes. Smith et al. (1991) suggested, based on mass balance analysis, that these two processes could dominate the net nonconservative flux of nitrogen in coastal lagoons. Results that are consistent with smaller scale biochemical assays have been conducted in coastal lagoons (Seitzinger 1988).

Access net system nonconservative carbon flux in NCLs may be not trivial, mostly due to $\mathrm{CaCO}_{3}$ reactions. Nonconservative uptake of total alkalinity has been used as a measure of $\mathrm{CaCO}_{3}$ reactions. Despite the conformity of this procedure in clearly calcifying systems like coral reefs, it does not work in systems with rapid sulfate reduction, like coastal lagoons. Sulfate reduction is probably an important pathway of organic oxidation in many sediment-dominated aquatic systems containing a significant fraction of seawater and exhibiting relatively high rates of metabolism in the sediment. Nielsen et al. 2004, studying different pathways of organic matter mineralization in the NCL from Rio de Janeiro state, observed that only $2 \%$ of $\mathrm{CO}_{2}$ flux from the sediment of these la- 
goons where attributed to sulfate reduction. This result was mainly attributed to the low concentration of sulfate in the sediment $(500 \mu \mathrm{M})$, and they specified $500 \mu \mathrm{M}$ to be the threshold of sulfate concentration to observed significant values of organic matter mineralization through this pathway. Although the authors attributed only a small fraction of carbon mineralization to sulfate reduction, they focused on lagoons with low to intermediate ocean influences. Many NCL are subjected to high ocean influences, and in these cases the contribution of sulfate reduction is expected to be higher.

According to the dominance of autotrophic populations, Knoppers (1994) distinguish coastal lagoons in three types. At one end of the spectrum are the phytoplankton-based systems with some seasonal contributions of micro- and macro phytobentos in shallow depths and with or without anaerobic autotrophic bacteria depending upon stratification of the water column and the stagnation and anoxia of bottom waters. The intermediate position holds the benthic macroalgal- and macrophytebased systems, and at the other end of the spectrum the algal mat systems of hypersaline lagoons and lagoons with intertidal zones that are subject to prolonged exposure during dry seasons. Knoppers (1994) highlighted several approaches and attempted to link the magnitude of primary production to physiographic and hydrological characteristics of coastal lagoons and estuaries. Included are studies on the dependence of phytoplankton doubling rates upon the tidal exchange ratio, on nutrient loading and primary production versus the dynamics of river run-off, tides, winds, water residence time and estuarine/ lagoon morphometry. All of these factors may act simultaneously, and there seems to be no simple link between a single physical factor and the magnitude of primary production and autotrophic biomass in coastal lagoons.

Smith and Atikinson (1994) presented a review of some studies and observed that shallow water marine ecosystems tend to be slight net consumers of organic material (in other words, net sinks of organic matter). However, net heterotrophy can be just a transient phenomenon, until the surplus of carbon biomass or buried organic carbon is consumed. Reyes and Merino (1991) presented a compilation of ten lagoons containing primary producers from phytoplankton to macrophytes. The majority were, on an annual basis, balanced to slight autotrophic. Other observations were obtained for various coastal lagoons, even in the southern Brazilian coast of Saquarema (Carmouze et al., 1991). No common metabolism can be found, and they vary from balanced to slightly auto- or heterotrophic (Knoppers, 1994). Coastal lagoons are especially interesting because they are often classified as "highly productive" and at the same time exhibit high respiration rates. In general, the pattern of net metabolism observed in these systems may be strongly dependent on the delivery of organic matter or inorganic nutrient into the system, which may favor either heterotrophy or autotrophy, respectively.
NCLs have a direct influence on the maintenance of groundwater supply and to climatic stability in local and regional terms. However, the general acknowledgment of its importance has been made through the extensive use by man of the products and services these systems provide. Esteves (1998) points out that, due to their high productivity, the coastal lagoons of Rio de Janeiro state have been exploited throughout the years and especially by fishing activities. According to Esteves (1998), such activities in turn gave origin to several cities in Rio de Janeiro state. Although the importance of NCLs is related, in most cases, to fishing, many products can be obtained from other organisms, for example aquatic macrophytes. Leaves of the macrophyte Typha domingensis are often used to manufacture objects that are used in ornamentation. This macrophyte and other species such as Eichhornia crassipes are also used in the production of food for animals and in the paper industry (Esteves 1998).

NCLs may represent an important element for industry and agriculture, since one basic condition for the development of these activities is the availability of fresh water, in reasonable quantity and quality. NCLs may have a great potential as a reservoir of freshwater that can also be dedicated to domestic use. Many of the services that these systems provide are basic components for the quality of life in many Brazilian cities (Esteves 1998), namely recreational areas, receptor of sewage, flood control, scenic beauty, tourism and the valorization of residential properties.

The maintenance of the ecological equilibrium of NCLs, therefore, represents an important element for the economy of many segments of the society. Profits can be earned from the maintenance of the quality of life in the regions where NCLs are located, through ordinary tourism or, in particular, through ecotourism.

\section{Identification and Description of the Main Threats Affecting NCLs}

Many singular characteristics of coastal lagoons already discussed make these systems more vulnerable to human-mediated impacts than other systems. As a consequence, the maintenance and conservation of their biodiversity and functioning is, in many cases, problematic. More impacts than we are currently observing will likely emerge in the coastal zones of developing countries such as those in the Neotropics, where government regulatory controls are less stringent or lacking compared to those of most developed countries (Kennish, 2002). Additionally, in developing countries where there are priorities that often come before environmental conservation, the threat of such impacts is predicted to continue to increase in all aquatic systems (Bronmark and Hansson, 2002). Many coastal areas in the Neotropical region are already impacted. In this section, we identify the most common problems facing NCLs and how their biodiversity and functioning are negatively affected. 
A large variety of impacts can be observed on NCLs. Such events may range from local to continental extensions, depending on their origin and source. Examples of common local impacts are watershed threats, eutrophication, chemical contaminants by heavy metals and pesticides, introduction of non-indigenous species, fishery overexploitation and artificial sandbar openings, which all lead to habitat loss and alteration, putting the functioning and conservation of NCL biodiversity at risk.

Watershed threats are probably prevalent around the world and are mostly associated with activities related to water quality and quantity and sediment delivery. Agriculture and silviculture are often the most important controllers of the quality and quantity of water exported from the watershed (Alexandridis et al., 2007). Siltation is a special problem in a number of Brazilian watersheds, especially when intensive agriculture reaches new frontiers (Agostinho et al., 2005). An additional watershed alteration is the construction of dams and channels on the shores of permanent sea-connected lagoons to enhance salt extraction. Such habitat modifications promoted by saltworks alter both the inflow of freshwater from the watershed and the runoff, thus directly affecting the water salinity.

The cultural eutrophication process is undoubtedly the most common problem affecting the biodiversity and functioning of NCLs. The negative consequences of nutrient enrichment by phosphorus and nitrogen on inland aquatic ecosystems are multiple and are known to occur worldwide (Vitousek et al., 1997; Carpenter et al., 1998). These impacts can drastically affect the composition, trophic structure and size/biomass patterns of community organization from algae to fish (Jeppesen et al, 2000). Regime shifts from clear to turbid water states are also expected, when such human-mediated stressors cause phytoplankton communities to be more prone to outcompeting aquatic macrophytes, changing shallow aquatic systems from a clear-water high-diversity state to a turbid-water low-diversity state (Scheffer et al., 1993). The accumulation of algae-derived microcystins in higher trophic levels is also noticed for zooplankton and fish from eutrophicated NCLs (De Magalhães et al., 2001; Ferrão-Filho et al., 2002) and certainly represents an unexpected and undesirable problem for people consuming fish, as in the Jacarepaguá lagoon (Southeast Brazil) (Magalhães et al., 2001). Eutrophic waters are also more susceptible to dissolved oxygen depletion, which can lead to the production of $\mathrm{H}_{2} \mathrm{~S}$ in the sediment and to high fish mortalities, as in the Rodrigo de Freitas lagoon (Southeast Brazil; personal observation).

The entrance and maintenance of chemical contaminants are becoming extremely common in NCLs, and in some cases their levels are above the predicted toxic effects to aquatic organisms. Heavy metals and compounds originating from pesticides are problematic toxic agents in coastal areas around the world. Some substances tend to bioaccumulate in aquatic organisms and, in some cases, biomagnify in food chains, reaching high concentrations in the upper trophic levels. Biotic disorders caused by heavy metals are summarized by Kennish (2002). The NCLs more impacted by chemical contaminants are those located in the vicinity of urban regions and agricultural lands. Indeed, Lacerda and Gonçalves (2001) found the highest concentrations of all $\mathrm{Hg}$ species in Rio de Janeiro (southeast Brazil) lagoons receiving runoff from urban areas when compared to more isolated lagoons that receive small fluvial inputs. Another example of chemical contaminants in NCLs comes from the district of Chinandega (Pacific coast of Nicaragua). In such systems, the concentration of toxaphene (a chemical pollutant derived from the use of pesticide in cotton plantations) and other pollutants showed levels generally high and worrying (Carvalho et al., 1999; 2003). Like algae-derived microcystin, the accumulation of chemical contaminants in fishes is a serious problem for people consuming them, and reduces the quality of potential services that NCLs can offer to local societies.

The introduction of non-indigenous species is another considerable threat for coastal lagoons, given the fact that this impact is one of the top 5 causes of changes in biodiversity on a global scale (Sala et al., 2000). For NCLs, there is little available data on either the species invading specific areas or the geographical ranges at which invasions succeed, and how these affect the lagoon's biodiversity and functioning. However, some examples exist. An example of this is the polychaete Ficopomatus enigmaticus, an exotic and ecosystem engineer reef-building species in the Mar Chiquita coastal lagoon, Argentina (Schwindt et al., 2001). Studies focused on this species suggest that the polychaete plays an important role in the hydrodynamics of the Mar Chiquita coastal lagoon by affecting the bedload transport and deposition of the sediment entering the system (Schwindt et al., 2004). Another widespread example is the occurrence of tilapias (Tilapia spp. and Oreochromis spp.) in many NCLs. Tilapias were, in many cases, intentionally introduced into NCLs in order to increase local fishery. However, the negative impacts of these exotic species were not considered and now tilapias have become a serious problem, diminishing the abundance of native species and possibly causing local extinctions. Overall in aquatic systems in Nicaragua, tilapia have become widely established and have been responsible for reducing the size and abundance of native species as well as eliminating native species as a food source in local fish markets (McCrary et al., 2007). Introduced tilapias are already disseminated in other NCLs (Caramaschi et al., 2004) and could act in similar ways to those observed in Nicaraguan aquatic systems, meaning an additional risk for NCL biodiversity and functioning.

Fishery overexploitation is another problem for the conservation of NCL biodiversity and functioning, especially with regard to fish species. Innovation in fishing technologies and overfishing affect the structure and diversity of fishing resources, destroy nursing habitats, capture smaller fishes and shrimps, and reduce natural 
stocks (Seixas and Troutt, 2004). For instance, Rueda and Santos-Martínez (1999) suggested that the striped mojarra Eugerres plumieri might be overexploited in terms of yield and biomass per recruit in the Ciénaga Grande de Santa Marta, Colombia. Two common features of coastal lagoons make these systems especially appreciable for fishing: the relatively small area and the high productivity rates (Esteves, 1998), allowing large fish stocks and a better fishing-efficiency. In this way, overfishing has direct negative consequences on NCL biodiversity and functioning, reducing natural stocks and altering the patterns of the trophic structure. Reduced natural stocks make populations more vulnerable to stochastic extinctions, alter the energy flux in the food chain and reduce the strength of biotic interactions. Recovery from such disturbances may be slow, especially for marine species in closed NCLs, as dispersion and recolonization is more difficult. In many cases, to facilitate this process, fishermen choose to artificially open the sandbar, allowing fish and fish larvae to enter the NCL, though this profoundly affects many other natural features.

The artificial connection of coastal lagoons to the sea creates a threat to these systems around the world (Thomas et al., 2005; Gladstone at al., 2006 and others) and this pattern is not different for NCLs, especially in Brazil (Suzuki et al., 2002; Kozlowsky-Suzuki and Bozelli, 2004). As previously discussed, coastal lagoons can be naturally connected to the sea or can represent intermittently opening estuaries, where marine intrusions are not likely to represent significant disturbances (Kibirige and Perissinotto, 2003, for a South African system). This is not the case for permanently closed-off freshwater coastal lagoons systems that are sporadically or permanently artificially opened (Attayde and Bozelli, 1998). The various reasons for artificial sandbar openings include: 1) fishery improvement; 2) water-level reduction to avoid inundation of residences and roads constructed near the shoreline; 3 ) water-quality improvement by exporting nutrients to the ocean; and 4) hypoxia risk reduction, among others. In these cases, the impacts of such disturbances are promptly reflected in the aquatic communities, especially due to water level reduction and increased salinities. A decrease in species richness and diversity is commonly observed for a variety of aquatic communities, in addition to changes in the biological composition, which may then show marine and estuarine characteristics (Saad et al., 2002; Santangelo et al., 2007). Salinity is a key factor acting on the osmorregulation of individuals (Remane and Schlieper, 1971). In addition, the areas most influenced by marine intrusions may show the highest UV penetration, as observed in Rocha coastal lagoon, Uruguay (Conde et al., 2000). Marine intrusions in the Rocha coastal lagoon also enhance the negative effect of solar UV radiation on phytoplankton photosynthetic rates (Conde et al., 2002). Changes in the primary production rates due to increased salinities could represent an extra factor contributing to alterations in the trophic structure and patterns of biodiversity. Finally, artificial sandbar openings have shown little efficiency in controlling NCL eutrophication since internal load by sediment phosphorus regeneration quickly enhances phosphorus concentrations in the water column.

Water level reduction by sandbar openings, river regulation and climate change (see below) is an additional threat for NCLs. Death of submerged macrophytes upon exposure to air increases dissolved and total nutrients, and primary production can shift from being macrophyteto phytoplankton-dominated. Huge and unpredictable droughts caused by sandbar openings promoted different responses in aquatic macrophytes from coastal lagoons in southeast Brazil. High mortality and changes in the aboveground biomass were observed for Eleocharis interstincta at the Cabiúnas lagoon (dos Santos and Esteves, 2004). On the contrary, drought by sandbar opening promoted the expansion of Eleocharis mutata beds at the Imboassica lagoon (Palma-Silva et al., 2000). Additionally, the decay of Typha domingensis stands due to the sandbar opening contributed to an increase in phosphorous in the water column at the Imboassica lagoon (dos Santos et al., 2006). It is possible to conclude that water level variation plays a fundamental role in the biology of emergent aquatic macrophytes in NCLs, regulating biomass, net primary productivity and nutrients among other biological attributes (dos Santos et al., 2006).

Broad- and continental-scale impacts are expected to be related mainly to global warming, increased $\mathrm{CO}_{2}$ levels, and a predicted scenario of increased sea level (Nicholls et al., 1999). Under this scenario, the biotic communities and productivity of coastal lagoons are likely to undergo a variety of changes, depending on whether and how a particular system's characteristics, such as its littoral area, freshwater flows and salt intrusion, are affected (Nicholls et al., 2007). Additionally, unpredictable synergisms among the negative impacts derived from artificial sandbar openings may occur with those derived from climate change (Magrin et al., 2007). Under a global warming scenario, NCLs will probably experience higher temperatures and increased salinities. Warmer waters will directly or indirectly mediate extinctions of those species less adapted to higher temperatures. At the same time, they may increase the chance of invasions by exotic species, as already reported for arid terrestrial systems (Smith et al., 2000), thus changing the NCL biodiversity. The same effects are predicted to occur via salinity alterations. Indeed, climate-induced salinity increases can drive coastal systems to a state of depleted zooplankton biodiversity and altered ecosystem functioning (Schallenberg et al., 2003). The interactive effects of multiple stressors, such as higher temperatures and increased salinities, under natural conditions are not yet understood, but laboratory experiments show a lower tolerance to salinity as temperature increases for some freshwater zooplankton (Hall and Burns, 2001; 2002).

Paleolimnological data obtained for a group of Uruguayan coastal lagoons has shown changes in the 
trophic state and salinity as a consequence of climate change since at least 7,000 years BP (García-Rodriguez et al., 2004; Inda et al., 2006 and others). As a consequence, the biological communities of these systems must have experienced drastic alterations at that time, as observed for diatoms (García-Rodriguez et al., 2004). Concomitant decreases in salinity and increases in trophic state were observed during marine regressions while the opposite pattern was observed during marine transgressions (García-Rodriguez et al., 2004; Inda et al., 2006). These data indicate that climate change has the potential to alter NCL biodiversity and functioning.

The intensification (both in frequency and magnitude) of the El-Niño Southern Oscillation (ENSO) in recent years is also attributed to human activities, and such events have altered the natural features of some NCLs. Climate variability in the form of ENSO was suggested to be largely responsible for high salinity increments in the first half of the 1990s in the Ciénaga Grande de Santa Marta and the Pajarales Complex coastal lagoons, Colombia (Blanco et al., 2006). Additionally, the fish community of the Patos lagoon estuary (south Brazil) was largely influenced by ENSO episodes, favoring euryhaline or freshwater species at different times (Garcia et al., 2001). Finally, the high resilience time of the freshwater zooplankton community of the Imboassica lagoon (southeast Brazil) after disturbance by salinity increase was partially attributed to low precipitation in the region during an El-Niño event (Santangelo et al., 2007).

If rainfall patterns are also modified by climate change, additional negative consequences will be imposed by NCLs. Rainfall is an important regulator of the hydrologic balance, determining the salinity ranges in the NCL. Precipitation has also been proposed to be a key mechanism regulating the rates at which allochtonous organic matter (mostly humic substances) enters some Brazilian coastal lagoons. The concentrations of coloured humic substances in these coastal lagoons has been shown to be high in the rainy season and lower in drier months (Farjalla et al., 2002; Suhett et al., 2007). Such climate-mediated alterations in terrestrial subsides may profoundly affect the aquatic biogeochemical environment since they modify the euphotic zone depth, the heat distribution in the system, the water $\mathrm{pH}$, the primary productivity and the whole-system metabolism (Esteves et al., 1988; Farjalla et al., 2002; Steinberg, 2003; Suhett et al., 2007). Finally, such habitat change is supposed to impact NCL biodiversity since it will: 1) modify the system productivity, altering the carrying capacity of populations; 2) interfere in visual-based predatory interactions, modifying species interaction strength; and 3) change the abiotic environment, affecting the physiology of individual plants and animals.

Human-mediated impacts affecting NCLs are common to many other disturbances affecting coastal lagoons worldwide. Analyses of global trends by Bronmark and Hansson (2002) suggest that well known threats to aquatic biodiversity, such as eutrophication, acidification and contamination by heavy metals and organochlorines, may become less of a problem in developed countries in the future. However, the opposite pattern is expected in developing countries. The importance of new threats such as global warming, ultraviolet radiation, endocrine disruptors and, especially, invasion by exotic species including transgenic organisms will most likely increase in the future (Bronmark and Hansson, 2002). Although many systems are already modified, others remain in relative pristine condition and could be used as target conditions for the recovery of impacted ones. Special care should be given to those systems harboring endemic species, high biodiversity, migratory birds and important human services.

\section{NCL Conservation and Management}

So far we have highlighted the main aspects concerning the value of NCL biodiversity and their derived ecosystem services, as well as how human-mediated activities are negatively affecting the functioning of NCLs. This way, we see a scenario of increasing degradation of NCLs, which requires the avoidance of oversimplified solutions that accommodate environmentalism and capitalism, or moral alternatives that separate a behavior from its historic and cultural trajectory or from the way society is structured. In the following, we will demonstrate why initiatives directed towards the conservation of NCLs should be plural, conjugating environmental public policies such as the establishment of protected areas, the licensing and control of potentially impacting enterprises, interdisciplinary scientific expertise, societal and economic aspects of local societies, public information and conservation awareness, and finally, actions to increase public participation and social control of decisions regarding the use of environmental resources.

For example, in Brazil, the State is the main mediator in the process of environmental management. In this process of mediation, it is responsible for the organization and control of the use of environmental resources. The State has the power to create economic and fiscal mechanisms, to compel the repairing of actual damage to the environment and many other inherent actions to its controlling function (Quintas et al., 2005). We consider this to be the best approach in orienting the relationship between man and nature because there is always a competition for the resources generating problems and usually producing conflicts. Traditionally, it has been accepted that environmental protection can be achieved through the adoption of two non-mutually exclusive strategies, a more restrictive one based on the implementation of protective areas and a more flexible one based on management practices. Deciding which of these will be more appropriate is a task that demands the establishment of priorities, since not all sites of potential interest can be conserved due to lack of financing and/or the need for the expansion of agriculture and/or housing (Myers et al., 2000). This is most certainly true in developing 
countries such those in the Neotropical region, where the basic needs of the population still have to be fulfilled (Bronmark and Hansson, 2002). Therefore, conserving NCLs is far from a simple task since most NCLs reside in densely populated regions where the majority of ecosystems are already under human pressure, which complicates the possibility of establishing protected areas. But even when it is possible to create a protected area, this is not a decision that should be taken without considering society's expectations and what is already established in national environmental policy. In most cases, conservation of NCLs will depend upon managementbased conservational practices which need to involve interdisciplinary scientific advisory, governmental officials and public commitment (Barbosa et al., 2004). For example, in a scientific interface, cooperation between distinct environmental disciplines such as geomorphology, hydrology and limnology will be fruitful since it has the potential to combine information about specific local biological dynamics with long-term ecosystem-level geomorphological processes to predict, for example, how NCLs will be locally affected by human interventions such as sand bar breaching or how NCLs will respond in a broader scale to global change scenarios. Such information can be used through a management interface by engineers to fit urban projects such as shoreline developments and watershed channelization or restoration strategies such as sediment dredging into a more sustainable fashion or into a less impacting practice. In a scientificsocio-economic interface, human sciences such as geography, sociology and anthropology can stimulate and coordinate participative discussions among members of traditional local societies (e.g. fishermen, saltworks), municipalities and non-governmental organizations. These discussions can subsidize local governance with precise societal, cultural and economic information, which, when combined with environmental knowledge, will ultimately guide effective decisionmaking for local coastal lagoon management. Finally, initiatives that raise public awareness and participation by increasing links between schools, colleges, universities and the general public, such as environmental education programs, should also be pursued since public commitment is an essential aspect of any conservational practices (Bozelli et al., 2004; Lopes, 2004).

Although management-based conservation is the most realistic practice to preserve NCL functioning, these systems are more than just the food that they produce or the environmental services that they provide. Hence, more restrictive natural reserves that conserve the regional pristine characteristics of NCLs as much as possible are also fundamental, since these systems are rare physiographic ecotones and support species adapted to thrive under high spatio-temporal environmental heterogeneity (Attayde and Bozelli, 1998; Santangelo, 2005; Laque, 2006). Such characteristics stress that NCLs are worth conserving in their own right, but also because they harbor environmentally plastic species which may be of key relevance to the maintenance of coastal biodiversity in a global change scenario (Barbosa et al., 2004). Integration of scientific expertise, government officials and commercial companies are also powerful strategies to overcome difficulties in establishing protected areas in Neotropical coastal regions. A successful example is the Restinga de Jurubatiba National Park located in Rio de Janeiro state (southeast Brazil), which comprises 19 coastal lagoons and is the only federal conservation unit preserving sandy coastal plains in Brazil (Barbosa et al., 2004). The creation of this National Park was due to an amalgamation of relevant scientific information about the biodiversity and functioning of its coastal lagoons and political articulation involving municipalities and the federal government. Furthermore, since 1998, environmental monitoring and research on a variety of aquatic and terrestrial ecosystems in Jurubatiba National Park, as well as local environmental education programs, have been sponsored mainly by Petrobras ${ }^{\circledR}$, the Brazilian oil company.

Finally, we finish this review by stressing the needs of Neotropical aquatic scientists to commit more attention to NCLs. Although these ecosystems are among the most valuable in the Neotropical coastal areas for both biodiversity and natural capital, they have been largely forgotten by freshwater and marine scientists, primarily because of their interface position and frequent alterations between fresh and salt water conditions. Current databases are insufficient to characterize either the dynamic nature of these systems or to serve as reference points for the development of sustainable management plans. Long-term spatial and temporal studies of these dynamic systems, including environmental monitoring and the collection of paleolimnological data, are necessary to put conservational strategies into the context of the major environmental problems which face NCLs.

Acknowledgements - We thank Dr. José Galisia Tundisi for inviting us to write this review. We are also indebted to CNPq, CAPES, FAPERJ and FINEP for scholarships and other financial support. Finally we thank PETROBRAS, the Prefeitura Municipal de Macaé, IBAMA, the staff of the Núcleo de Desenvolvimento Sócio-Ambiental de Macaé (NUPEM/ UFRJ) and all past and present members of the Laboratório de Limnologia (UFRJ) for unconditional financial and/or logistical support since the beginning of ecological studies in coastal lagoons in the northeast region of Rio de Janeiro state (Brazil).

\section{References}

AGOSTINHO, AA., THOMAZ, SM. and GOMES, LC., 2005. Conservation of the biodiversity of Brazil's inland waters. Conserv. Biol., vol. 19, no. 3, p. 646-652.

ALEXANDRIDIS, TK., TAKAVAKOGLOU, V., ZALIDIS, GC. and CRISMAN, TL., 2007. Remote sensing and GIS techniques for selecting a self-sustainable scenario for Lake Koronia. J. Envir. Management, vol. 39, no. 2, p. 278-290.

ATTAYDE, JL. and BOZELLI, RL., 1998. Assessing the indicator properties of zooplankton assemblages to disturbance 
gradients by canonical correspondence analysis. Can. J. Fish. Aquat. Sci., vol. 55, no. 8, p. 1789-1797.

BARBOSA, FAR., SCARANO, FR., SABARÁ, MG. and ESTEVES. FA., 2004. Brazilian LTER: Ecosystem and Biodiversity of Brazilian LTER. Environ. Monit. Assess., vol. 90 , no. 1-3, p. 121-133.

BERKES, F. and SEIXAS, CS., 2005. Building resilience in lagoon social-ecological systems: a local level perspective. Ecosystems, vol. 8, no. 8, p. 967-974.

BIRD, ECF., 1994. Physical setting and geomorphology of coastal lagoons. In KJERFVE, B. (Ed.). Coastal Lagoon processes. Amsterdam, The Netherlands: Elevier. Elsevier Oceanography Series, vol. 60, p. 9-40.

BLANCO, JA., VILORIA, EA. and NARVAEZ JC., 2006. ENSO and salinity changes in the Cienaga Grande de Santa Marta coastal lagoon system, Colombian Caribbean. Estuar. Coast. Shelf Sci., vol. 66, no. 1-2, p. 157-167.

BOTERO, L. and SALZWEDEL, H., 1999. Rehabilitation of the Cienaga Grande de Santa Marta, a mangrove-estuarine system in the Caribbean coast of Colômbia. Ocean Coast. Manag., vol. 42, no. 2-4, p. 243-256.

BOZELLI, RL., FERREIRA, DM., ESTEVES, FA., ROCHA, AM. and LOPES, AF., 2004. Educação Ambiental: Um processo embasado no conhecimento científico em longo prazo e determinante no cuidado com a natureza. In ROCHA, CFD., ESTEVES, FA., and SCARANO, FR. (Eds.). Pesquisas de longa duração na Restinga de Jurubatiba: ecologia, história natural e conservação. São Carlos, São Paulo, Brasil: RIMA. p. 361-374.

BRONMARK, C. and HANSSON, LA., 2002. Environmental issues in lakes and ponds: current state and perspectives. Envir. Conserv., vol. 29, no. 3, p. 290-307.

CALDAS, LHD., DE OLIVEIRA, JG. and DE MEDEIROS, WE., 2006. Geometry and evolution of Holocene transgressive and regressive barriers on the semi-arid coast of NE Brazil. Geo-Mar. Lett., vol. 26, no. 5, p. 249-263.

CALIMAN, A., 2005a. Biodiversidade e funcionamento de ecossistemas aquáticos. Boletim da Sociedade Brasileira de Limnologia. Available from: <http://www.sblimno.org.br/ Boletim-arquivos/bol_sbl_33.pdf

-, 2005b. Biodiversidade de macroinvertebrados bentônicos e funcionamento de ecossistemas aquáticos: uma abordagem experimental. Rio de Janeiro: PPGE/UFRJ. 96 p. [Master Thesis].

CALIMAN, A., LEAL, JJF., CARNEIRO, LS., ESTEVES, FA., BOZELLI, RL. and FARJALLA, VF., 2007. Functional bioturbator diversity enhances benthic-pelagic processes and properties in experimental microcosms. J. North Am. Benth. Soc., vol. 26 , no. 3 , p. 450-459.

CARMOUZE, JP., KNOPPERS, B. AND VASCONCELLOS, P., 1991. Metabolism of a subtropical Brazilian lagoon. Biogeochemistry, vol. 14, no. 2, p. 129-148.

CARAMASCHI, EP., SÁNCHEZ-BOTERO, JI., HOLLANDACARVALHO, P., BRANDÃO, CAS., SOARES, CL., NOVAES, JLC. and BARTOLETTE, R., 2004. Peixes das lagoas costeiras do Norte Fluminense: estudo de caso. In ROCHA, CFD., ESTEVES, FA., and SCARANO, FR. (Ed.). Pesquisas de longa duração na Restinga de Jurubatiba: ecologia, história natural e conservação. São Carlos, São Paulo, Brazil: RIMA. p. 309-337.

CARPENTER, SR., CARACO, NF., CORRELL, DL., HOWARTH RW., SHARPLEY, AN. and SMITH VH., 1998. Nonpoint pollution of surface waters with phosphorus and nitrogen. Ecol. Appl. vol. 8, no. 3, p. 559-568

CARVALHO, FP., MONTENEGRO-GUILLEN, S., VILLENEUVE, JP., CATTINI, C., TOLOSA, I., BARTOCCI, J., LACAYO-ROMERO, M. and CRUZ-GRANJA, A., 2003. Toxaphene residues from cotton fields in soils and in the coastal environment of Nicaragua. Chemosphere, vol. 53, no. 6, p. $627-636$

CARVALHO, FP., MONTENEGRO-GUILLEN, S., VILLENEUVE, JP., CATTINI, C., BARTOCCI, J., LACAYO, M. and CRUZ, A., 1999. Chlorinated hydrocarbons in coastal lagoons of the Pacific coast of Nicaragua. Arc. Envir. Contam. Toxic., vol. 36, no. 2, p. 132-139.

CONDE, D., AUBRIOT, L. and SOMMARUGA, R., 2000. Changes in UV penetration associated with marine intrusions and freshwater discharge in a shallow coastal lagoon of the Southern Atlantic Ocean. Mar. Ecol. Prog. Ser., vol. 207, p. 19-31.

CONDE, D., AUBRIOT, L., BONILLA, S. and SOMMARUGA, R., 2002. Marine intrusions in a coastal lagoon enhance the negative effect of solar UV radiation on phytoplankton photosynthetic rates. Mar. Ecol. Prog. Ser., vol. 240, p. 57-70.

DE MAGALHAES, VF., SOARES RM. and AZEVEDO, SMFO., 2001. Microcystin contamination in fish from the Jacarepagua Lagoon (Rio de Janeiro, Brazil): ecological implication and human health risk. Toxicon, vol. 39, no. 7, p. $1077-1085$.

DE PAGGI, SJ., BRANCO, CWC., and KOZLOWSKYSUZUKI, B., 2000. Description of Macrochaetus kostei n. sp (Rotifera, Trichotriidae) from a coastal lagoon of Rio de Janeiro, Brazil. Studies on Neot. Fauna Envir, vol. 35, no. 2, p. $157-160$

ESTEVES, FA., and LACERDA, LD., 2000. Ecologia de Restingas e Lagoas Costeiras. Rio de Janeiro: Núcleo de Pesquisas Ecológicas de Macaé (NUPEM/UFRJ).

ESTEVES, FA., 1989. Fundamentos de Limnologia. Rio de Janeiro: Interciência/FINEP.

-, 1998. Lagoas costeiras: origem, funcionamento e possibilidades de manejo. In Esteves, FA. (Ed.). Ecologia das Lagoas Costeiras do Parque Nacional da Restinga de Jurubatiba e do Município de Macaé (RJ). Rio de Janeiro: Nupem/UFRJ, p. 63-90.

-, 1998. Lagoa Imboassica: impactos antrópicos, propostas mitigadoras e sua importância para a pesquisa ecológica. In Esteves, FA. (Ed.). Ecologia das Lagoas Costeiras do Parque Nacional da Restinga de Jurubatiba e do Município de Macaé (RJ). Rio de Janeiro: Nupem/UFRJ, p. 464-472.

ESTEVES, FA., BOZELLI, RL., CAMARGO, AFM., ROLAND, F. and THOMAZ, SM., 1988. Variação diária (24 horas) de temperatura, $\mathrm{O}_{2}$ dissolvido, $\mathrm{pH}$ e alcalinidade em duas lagoas costeiras do estado do Rio de Janeiro e suas implicações no metabolismo destes ecossistemas. Acta Limnol. Brasil., vol. 11, no. 2, p. 99-127.

ESTEVES, FA., SCARANO, FR., and FURTADO, ALS., 2002. Restingas e lagoas costeiras do norte fluminense. In SEELIGER, U., CORDAZZO, C. and BARBOSA, FAR. (Ed.). 
Os sites e o Programa Brasileiro de Pesquisas Ecológicas de Longa Duração. Belo Horizonte: Universidade Federal de Minas Gerais, p. 83-100.

EVANS RD., 1994. Empirical-Evidence of the importance of resuspended sediment in lakes. Hydrobiologia, vol. 284, no. 1, p. 5-12.

FARJALLA, VF., FARIA, BM. and ESTEVES, FA., 2002. The relationship between DOC and planktonic bacteria in tropical coastal lagoons. Arch. Hydrobiol., vol. 156, no. 1, p. 97-119.

FERRAO-FILHO, AD., KOZLOWSKY-SUZUKI, B. and AZEVEDO, S., 2002. Accumulation of microcystins by a tropical zooplankton community. Aquat. Toxic., vol. 59, no. 3-4, p. $201-208$.

GARCIA, AM., BEMVENUTI, MA., VIEIRA, JP., MARQUES, DMLM., BURNS, MDM., MORESCO, A. and CONDINI, MVL., 2006. Checklist comparison and dominance patterns of the fish fauna at Taim Wetland, South Brazil. Neotrop. Ichthyol., vol. 4 , no. 2 , p. 261-268.

GARCIA, AM., VIEIRA, JP. and WINEMILLER, KO., 2001. Dynamics of the shallow-water fish assemblage of the Patos Lagoon estuary (Brazil) during cold and warm ENSO episodes. J. Fish Biol., vol. 59, no. 5, p. 1218-1238.

GARCIA-RODRÍGUEZ, F., SPRECHMANN, P., METZELTIN, D., SCAFATI, L., MELENDI, DL., VOLKHEIMER, W., MAZZEO, N., HILLER, A., VON TUMPLING Jr. W. and SCASSO F., 2004. Holocene trophic state changes in relation to sea level variation in Lake Blanca, SE Uruguay. J. Paleol., vol. 31, no. 1, p. 99-115.

GASTON, KJ., 2000. Global patterns in biodiversity. Nature, vol. 405 , no. 6783 , p. $220-227$.

GIKAS, GD., YIANNAKOPOULOU, T. and TSIHRINTZIS, VA., 2006. Water quality trends in a coastal lagoon impacted by non-point source pollution after implementation of protective measures. Hydrobiologia, vol. 563, p. 385-406.

GLADSTONE, W., HACKING N. and OWEN, V., 2006. Effects of artificial openings of intermittently opening estuaries on macroinvertebrate assemblages of the entrance barrier. Estuar. Coast. Shelf Sci., vol. 67, no. 4, p. 708-720.

GÖNENÇ, IE. and WOLFLIN, JP., 2004. Coastal lagoons: ecosystem processes and modeling for sustainable use and development. New York: CRC Press.

HALL, CJ. and BURNS, CW., 2001. Effects of salinity and temperature on survival and reproduction of Boeckella hamata (Copepoda: Calanoida) from a periodically brackish lake. $J$. Plankton Res., vol. 23, no. 1, p. 97-103.

-, 2002. Mortality and growth responses of Daphnia carinata to increases in temperature and salinity. Freshwater Biol., vol. 47, no. 3 , p. $451-458$.

HOOPER, DU., CHAPIN, FS., EWEL, JJ., HECTOR, A., INCHAUSTI, P., LAVOREL, S., LAWTON, JH., LODGE, DM., LOREAU, M., NAEEM, S., SCHMID, B., SETALA, H., SYMSTAD, AJ., VANDERMEER, J. and WARDLE, DA., 2005. Effects of biodiversity on ecosystem functioning: A consensus of current knowledge. Ecol. Monog., vol. 75, no. 1, p. 3-35.

INDA, H., GARCÍA-RODRÍGUEZ, F., PUERTO, L., ACEVEDO, V., METZELTIN, D., CASTIÑEIRA, C., BRACCO, R., ADAMS, J. 2006. Relationships between trophic state, paleosalinity and climatic changes during the first holocene marine transgression in Rocha Lagoon, southern Uruguay. J. Paleol., vol. 35, no. 4, p. 699-713.

JEPPESEN E., SONDERGAARD M., PEDERSEN AR., JURGENS K., STRZELCZAK A., LAURIDSEN TL. and JOHANSSON LS., 2007. Salinity induced regime shift in shallow brackish lagoons. Ecosystems, vol. 10, no. 1, p. 47-57.

JEPPESEN, E., JENSEN, JP., SONDERGAARD, M., LAURIDSEN, T. and LANDKILDEHUS, F., 2000. Trophic structure, species richness and biodiversity in Danish lakes: changes along a phosphorus gradient. Freshwater Biol., vol. 45, no. 2, p. 201-218.

JEPPESEN E, SØNDERGAARD M, KANSTRUP E, PETERSEN B, HENRIKSEN RB, HAMMERSHØJ M., MORTENSEN E., JENSEN, JP. and HAVE, A., 1994. Does the impact of nutrients on the biological structure and function of brackish and freshwater lakes differ? Hydrobiologia, vol. 275, no. 1 , p. $15-30$

KENNISH, MJ., 2002. Environmental threats and environmental future of estuaries. Envir. Conserv., vol. 29, no. 1, p. 78-107.

KIBIRIGE, I. and PERISSINOTO, R., 2003. The zooplankton community of the Mpenjati estuary, a South African temporarily open/closed system. Estuar. Coast. Shelf Sci., vol. 58, no. 4, p. $727-741$

KJERFVE, B., 1994. Coastal lagoon processes. In KJERFVE, B. (Ed.). Coastal lagoon processes. Amsterdam, The Netherlands: Elsevier. Elsevier Oceanography Series, vol. 60, p. 1-8.

KOZLOWSKY-SUZUKI, B. and BOZELLI, RL., 2004. Resilience of a zooplankton community subjected to marine intrusion in a tropical coastal lagoon. Hydrobiologia, vol. 522, no. 1-3, p. 165-177.

LACERDA, LD. and GONCALVES, GO., 2001. Mercury distribution and speciation in waters of the coastal lagoons of Rio de Janeiro, SE Brazil. Marine Chemistry, vol. 76, no. 1-2, p. 47-58.

LAQUE, T., 2006. Variação sazonal e especial da composição de bactérias planctônicas em lagoas costeiras. Rio de Janeiro: PPGE/UFRJ, 79 p. [Master Thesis].

LARDICCI, C., COMO, S., CORTI, S. and ROSSI, F., 2001. Changes and recover of macrozoobenthic communities after restoration measures of the Orbetello Lagoon (Tyrrhenian coast, Italy). Aquatic Conserv. Mar. Freshwater Ecosyst., vol. 11, no. 4 , p. 281-287.

LOPES, AF., 2004. A medição de conceitos e a consolidação de uma proposta de trabalhos entre escola e universidade. Rio de Janeiro: PPGE/UFRJ. 90 p. [Master Thesis]

LOPES, PM. 2005. Composição da microfauna associada às macrófitas aquáticas de diferentes complexidades arquiteturais na lagoa Cabiúnas, Macaé, RJ. Rio de Janeiro: UNIRIO, 46 p. [Monografia de Graduação].

KNOPPERS, B., 1994. Aquatic Primary Production in Coastal Lagoons. In KJERFVE, B. (Ed.). Coastal lagoon processes. Amsterdam, The Netherlands: Elsevier. Elsevier Oceanography Series, vol 60, p. 243-285.

MACINTOSH, DJ., 1994. Aquaculture in coastal lagoons. In KJERFVE, B. (Ed.). Coastal Lagoon Processes. Amsterdam, The Netherlands: Elsevier. Elsevier Oceanography Series, vol 60, p. 401-442. 
MAGRIN, G., GAY-GARCÍA, C., CRUZ-CHOQUE, D., GIMÉNEZ, JC., MORENO, AR., NAGY, GJ., NOBRE, C. and VILLAMIZAR, A., 2007. Latin America. Climate Change 2007: Impacts, Adaptation and Vulnerability. In PARRY, ML., CANZIANI, OF., PALUTIKOF, JP., VAN DER LINDEN, PJ. and HANSON, CE. (Eds.). Contribution of Working Group II to the Fourth Assessment Report of the Intergovernmental Panel on Climate Change. Cambridge, UK: Cambridge University Press. p. 581-615.

MARGALEF, R., 1983. Limnología. Barcelona: Ediciones Omega. Platón 26.

MCCRARY, JK., MURPHY, BR., STAUFFER, JR. and HENDRIX, SS., 2007. Tilapia (Teleostei: Cichlidae) status in Nicaraguan natural waters. Envir. Biol. Fishes, vol. 78, p. $107-114$.

MELO S., TORGAN LC., MENEZES M., HUSZAR VLM., CORREA JD. and BOZELLI RL., 2003. Taxonomy and ecology of Synedropsis roundii sp nov (Bacillariophyta) from a tropical brackish coastal lagoon, south-eastern Brazil. Phycologia, vol. 42, no. 1, p. 71-79.

MILLENNIUM ECOSYSTEM ASSESSMENT, 2005. Ecosystems and Human Well-being: Synthesis. Washington, DC: Island Press.

MORAN, MA., POMEROY, LR., SHEPPARD, ES., ATKINSON, LP. and HODSON, RE., 1991. Distribution of terrestrially derived dissolved organic matter on the southeastern U.S. continental shelf. Limnol. Oceanogr. vol. 36, no. 6, p. $1134-1149$.

MYERS, N., MITTERMEIER, RA., MITTERMEIER, CG., DA FONSECA, GAB. and KENT, J., 2000. Biodiversity hotspots for conservation priorities. Nature, vol. 403, no. 6772, p. 853-858.

NICHOLLS, RJ., HOOZEMANS, FMJ. and MARCHAND, M., 1999. Increasing flood risk and wetland losses due to global sealevel rise: regional and global analyses. Global Envir. ChangeHuman and Policy Dimensions, vol. 9, p. S69-S87.

NICHOLLS, RJ.,WONG,PP.,BURKETT,VR.,CODIGNOTTO, JO., HAY, JE., MCLEAN, RF., RAGOONADEN, S. and WOODROFFE, CD., 2007. Coastal systems and low-lying areas. Climate Change 2007: Impacts, Adaptation and Vulnerability. In PARRY, ML., CANZIANI, OF., PALUTIKOF, JP., VAN DER LINDEN, PJ., and HANSON, CE. (Eds.). Contribution of Working Group II to the Fourth Assessment Report of the Intergovernmental Panel on Climate Change. Cambridge, UK: Cambridge University Press. p. 315-356.

NIELSEN, LP., PRAST, A. and ESTEVES, FA., 2004. Pathways of organic matter mineralization and nitrogen regeneration in the sediment of five tropical lakes. Acta Limnol. Brasil. vol. 16, no. 2, p. 193-202.

PAIVA, TD. and DA SILVA-NETO, ID., 2005. Deviata estevesi sp n. (Ciliophora: Spirotrichea), a new ciliate protist from a restinga lagoon in Rio de Janeiro, Brazil. Acta Protozool., vol. 44, no. 4, p. 351-362.

PANOSSO, R., and ESTEVES, FA., 2000. Regeneração do fósforo através da fosfatase extracelular em duas lagoas costeiras submetidas a diferentes graus de impactos antrópicos. In ESTEVES, FA. and LACERDA, LD. (Eds.). Ecologia de Restingas e Lagoas Costeiras. Rio de Janeiro: Núcleo de Pesquisas Ecológicas de Macaé (NUPEM/UFRJ), p. 277-294.
PANOSSO, RF., ATTAYDE, JL. and DIETER, M., 1998. Morfometria das lagoas Imboassica, Cabiúnas, Comprida e Carapebus: implicações para seu funcionamento e manejo. In ESTEVES, FA. (Ed.). Ecologia das Lagoas Costeiras do Parque Nacional da Restinga de Jurubatiba e do Município de Macaé $(R J)$. Macaé, Rio de Janeiro, Brazil: Nupem/UFRJ. p. 91-108.

QUINTAS, JS., GOMES, PM. and UEMA, EE., 2005. Pensando e praticando a Educação Ambiental no Processo de Gestão Ambiental: Uma concepção pedagógica e metodológica para a prática da educação ambiental no licenciamento. Brasília: MMA, Ibama. Coleção Meio Ambiente, no. 9, 47 p.

REID, JW., and ESTEVES, FA., 1984. Considerações ecológicas e biogeográficas sobre a fauna de copépodos (Crustacea) planctônicos e bentônicos de 14 lagoas costeiras do Estado do Rio de Janeiro, Brasil. In: L. D. Lacerda, R. Cerqueira and B. Turcq (ed.), Restinga: Origem, Estrutura, Processos. Rio de Janeiro, Brazil, p. 305-326.

REID, JW., 1985. Calanoid copepods (Diaptomidae) from coastal lakes, state of Rio de Janeiro, Brazil. Proc. Biol. Soc. Wash., vol. 98 , no. 3, p. 574-590.

REMANE, A. and SCHLIEPER, C., 1971. Biology of Brackish Water. Stuttgart: Wiley interscience division, $372 \mathrm{p}$.

REYES, M., and MERINO, M. 1991. Diel dissolved oxygen dynamics and eutrophication in ashallow well-mixed tropical lagoon (Cancun, Mexico). Estuaries, vol. 14, no. 4, p. 372-381.

RICCIARDI, A. and RASMUSSEN, JB., 1999. Extinction rates of North American freshwater fauna. Conserv. Biol., vol. 13, no. 5, p. 1220-1222.

RUEDA, M. and SANTOS-MARTINEZ, A., 1999. Population dynamics of the striped, mojarra Eugerres plumieri from the Cienaga Grande de Santa Marta, Colombia. Fisheries Res., vol. 42 , no. 1-2, p. 155-166.

SAAD, AM., BEAUMORD, AC. and CARAMASCHI, EP., 2002. Effects of artificial canal openings on fish community structure of Imboassica coastal lagoon, Rio de Janeiro, Brazil. J. Coastal Res., vol. 36, p. 634-639.

SALA, OE., CHAPIN, FS., ARMESTO, JJ., BERLOW, E., BLOOMFIELD, J., DIRZO, R., HUBER-SANWALD, E., HUENNEKE, LF., JACKSON, RB., KINZIG, A., LEEMANS, R., LODGE, DM., MOONEY, HA., OESTERHELD, M., POFF, NL., SYKES, MT., WALKER, BH., WALKER, M. and WALL, DH., 2000. Biodiversity - Global biodiversity scenarios for the year 2100. Science, vol. 287, no. 5459, p. 1770-1774.

SANTANGELO, JM. 2005. Influência da salinidade sobre a comunidade zooplanctônica de uma lagoa costeira. Rio de Janeiro: PPGE/UFRJ. 85 p. [Master thesis].

SANTANGELO, JM., ROCHA, AM., BOZELLI, RL., CARNEIRO, LS. and ESTEVES, FA., 2007. Zooplankton responses to sandbar opening in a tropical eutrophic coastal lagoon. Estuar. Coast. Shelf Sci., vol. 71, no. 3-4, p. 657-668.

SCHALLENBERG, M., HALL, CJ., and BURNS, CW., 2003. Consequences of climate-induced salinity increases on zooplankton abundance and diversity in coastal lakes. Mar. Ecol. Prog. Ser., vol. 251, p. 181-189.

SCHEFFER, M., 1998. Ecology of shallow lakes. Dordrecht, The Netherlands: Kluwer Academic Publishers. 
SCHEFFER, M., PORTIELJ, ER., and ZAMBRANO, L., 2003. Fish facilitate wave resuspension of sediment. Limnol. Oceanogr. vol. 48, no. 5, p. 1920-1926.

SCHEFFER, M., HOSPER, SH., MEIJER, ML., MOSS, B. and JEPPESEN, E., 1993. Alternative equilibria in shallow lakes. Tree, vol. 8, no. 8, p. 275-279.

SCHWINDT, E., BORTOLUS, A. and IRIBARNE, O., 2001. Invasion of a reef-builder polychaete: direct and indirect impacts on the native benthic community structure. Biol. Invasions, vol. 3 , no. 2, p. 137-149.

SCHWINDT, E., IRIBARNE, OO. and ISLA, FI., 2004. Physical effects of an invading reef-building polychaete on an Argentinean estuarine environment. Estuar. Coast. Shelf Sci., vol. 59, no. 1, p. 109-120.

SEIXAS, C. and TROUTT, E., 2004. Socio-economic and ecological feedbacks in lagoon fisheries: Management principles for a co-evolutionary setting. Interciencia, vol. 29, no. 7 , p. 362-368.

SMITH, NP., 1994. Water, salt and heat balances of coastal lagoons. In Kjerfve, B. (Ed.). Coastal Lagoon processes. Amsterdam, The Netherlands: Elsevier. Elsevier Oceanography Series., vol. 60, p. 69-102.

SMITH, SVS. and ATKINSON, MJ., 1994. Mass Balance of Nutrient Fluxes in Coastal Lagoons. In KJERFVE, B. (Ed.). Coastal lagoon processes. Amsterdam, The Netherlands: Elsevier. Elsevier Oceanography Series, vol. 60, p. 133-155.

SMITH, SD., HUXMAN, TE., ZITZER, SF., CHARLET, TN., HOUSMAN, DC., COLEMAN, JS., FENSTERMAKER, LK., SEEMANN, JR. and NOWAK, RS., 2000. Elevated CO, increases productivity and invasive species success in an arid ecosystem. Nature, vol. 408 , no. 6808 , p. 79-82.

SEITZINGER, SP., 1988. Denitrification in freshwater and marine ecosystems: ecological and geochemical significance. Limnol. Oceanogr., vol. 27, no. 6, p. 1015-1028.

SMITH, SV., HOLLIBAUGH, JT., DOLLAR, SJ., and VINK, S., 1991. Tomales Bay metabolism: C-N-P stoichiometry and ecosystem heterotrophy at the land-sea interface. Estuar. Coast. Shelf Sci., vol.33, no. 3, p. 223-257.

SOSA-LÓPEZ, A., MOUILLOT, D., RAMOS-MIRANDA, J., FLORES-HERNANDEZ, D. and CHI, TD., 2007. Fish Species richness decreases with salinity in tropical coastal lagoons. $J$. Biogeogr., vol. 34, no. 1, p. 52-61.

STEINBERG, CEW., 2003. Ecology of humic substances in freshwaters: from whole-lake geochemistry to ecological niche determination. Berlim: Springer.

SUHETT, AL., 2007. Efeito da biodiversidade de macrófitas aquáticas sobre sua decomposição. Rio de janeiro: PPGE/ UFRJ. 97 p. [Master thesis].
SUHETT, AL., AMADO, AM., ENRICH-PRAST, A., ESTEVES, FA. and FARJALLA, VF., 2007. Seasonal changes of dissolved organic carbon photo-oxidation rates in a tropical humic lagoon: the role of rainfall as a major regulator. Can. J. Fish. Aquat. Sci., vol. 64, p. 1266-1272.

SUZUKI, MS., FIGUEIREDO, RO., CASTRO, SC., SILVA, CF., PEREIRA, EA., SILVA, JA. and ARAGON, GT., 2002. Sand bar opening in a coastal lagoon (Iquipari) in the northern region of Rio de Janeiro State: hydrological and hydrochemical changes. Braz. J. Biol. = Rev. Bras. Biol., vol. 62, no. 1, p. 51-62.

SØNDERGAARD, M. and MIDDELBOE, M., 1995. A crosssystem analysis of labile dissolved organic carbon. Mar. Ecol. Prog. Ser. vol. 118, no. 1-3, p. 283-294.

THOMAS, CM., PERISSINOTO, R. and KIBIRIGE, I., 2005. Phytoplankton biomass and size structure in two South African eutrophic, temporarily open/closed estuaries. Estuar. Coast. Shelf Sci., vol. 65, no. 1-2, p. 223-238.

THOMSON CORPORATION, 2005. Web of Science. Institute for Scientific Information. [Accessed August 2007]. Available from: <http://go5.isiknowledge.com>.

TSIHRINTZIS, VA., SYLAIOS, GK., SIDIROPOULOU, M. and KOUTRAKIS. ET., 2007. Hydrodynamic modeling and management alternatives in a Mediterranean, fishery exploited, coastal lagoon. Aquacult. Engineer., vol. 36, no. 3, p. 310-324.

VAN SLUYS, M., ROCHA, CFD., HATANO, FH., BOQUIMPANI-FREITAS, L. and MARRA, RV., 2004. Anfíbios da Restinga de Jurubatiba: composição e história natural. In ROCHA, CFD., ESTEVES, FA., and SCARANO, FR., (Ed.). Pesquisas de longa duração na Restinga de Jurubatiba: ecologia, história natural e conservação. São Carlos, São Paulo, Brazil: RIMA. p. 165-178.

VEIGA, LA., DE OLIVEIRA, AT. and GASTAL, NA., 1995. Birds of the ecological station of Taim, RS, Brazil. Arq. Biol. Tecn., vol. 38, no. 2, p. 669-678.

VITOUSEK, PM., ABER, JD., HOWARTH, RW., LIKENS, GE., MATSON, PA., SCHINDLER, DW., SCHLESINGER WH. and TILMAN, DG., 1997. Human alteration of the global nitrogen cycle: Sources and consequences. Ecol. Appl., vol. 7, no. 7 , p. 737-750.

YOSHIDA, T., JONES, LE., ELLNER, SP., FUSSMANN, GF. and HAIRSTON, NG., 2003. Rapid evolution drives ecological dynamics in a predator-prey system. Nature, vol. 424, no. 6946, p. 303-306.

WETZEL, RG., 1991. Extracellular enzymatic interpretations: storage, redistribution, and interspecific comunication. In Chróst, RJ. (Ed.). Microbial Enzymes in aquatic environments. New York: Springer-Verlag. p. 6-28.

-, 1992. Wetlands as metabolic gates. J. Great Lakes Res. vol. 18 , no. 4 , p. 529-532. 